\title{
Mouse Systems to Model Hepatitis C Virus Treatment and Associated Resistance
}

\author{
Ahmed Atef Mesalam 1,2, Koen Vercauteren ${ }^{1,3}$ and Philip Meuleman ${ }^{1, *}$ \\ 1 Center for Vaccinology, Department of Clinical Chemistry, Microbiology and Immunology, Ghent University, \\ Ghent 9000, Belgium; ahmed.mesalam@ugent.be (A.A.M.); koen.vercauteren@ugent.be (K.V.) \\ 2 Therapeutic Chemistry Department, National Research Centre (NRC), Dokki, Cairo 12622, Egypt \\ 3 Laboratory of Virology and Infectious Disease, The Rockefeller University, New York, NY 10065, USA \\ * Correspondence: philip.meuleman@ugent.be; Tel.: +32-9-332-36-58
}

Academic Editor: Thomas F. Baumert

Received: 23 February 2016; Accepted: 16 June 2016; Published: 22 June 2016

\begin{abstract}
While addition of the first-approved protease inhibitors (PIs), telaprevir and boceprevir, to pegylated interferon (PEG-IFN) and ribavirin (RBV) combination therapy significantly increased sustained virologic response (SVR) rates, PI-based triple therapy for the treatment of chronic hepatitis C virus (HCV) infection was prone to the emergence of resistant viral variants. Meanwhile, multiple direct acting antiviral agents (DAAs) targeting either the HCV NS3/4A protease, NS5A or NS5B polymerase have been approved and these have varying potencies and distinct propensities to provoke resistance. The pre-clinical in vivo assessment of drug efficacy and resistant variant emergence underwent a great evolution over the last decade. This field had long been hampered by the lack of suitable small animal models that robustly support the entire HCV life cycle. In particular, chimeric mice with humanized livers (humanized mice) and chimpanzees have been instrumental for studying HCV inhibitors and the evolution of drug resistance. In this review, we present the different in vivo HCV infection models and discuss their applicability to assess HCV therapy response and emergence of resistant variants.
\end{abstract}

Keywords: HCV; animal models; therapy; direct acting antiviral agents; humanized mice; resistance; deep sequencing

\section{Introduction}

The hepatitis C virus (HCV) was identified in 1989 as the etiologic agent for non-A non-B hepatitis [1]. It is a major health problem with more than 170 million people infected worldwide. Approximately $80 \%$ of infected patients evolve to chronicity, which can ultimately progress to liver cirrhosis and hepatocellular carcinoma (HCC) [2]. HCV is a small enveloped positive-stranded RNA virus that belongs to the Hepacivirus genus and the Flaviviridae family. It is classified into seven genotypes and multiple different subtypes, which exhibit differences in pathogenesis and response to treatment. $\mathrm{HCV}$ of genotype 1 is the most common genotype worldwide and in developed nations [3]. Once HCV enters its host cell, the hepatocyte, the viral genome is translated into a polyprotein precursor that is cleaved into a set of structural and non-structural proteins. While this cleavage process is initiated by host peptidases that release the structural proteins of the virus, the non-structural proteins are cleaved by viral cysteine and serine proteases (Figure 1). The structural proteins include the core protein that forms the capsid of the virus, and the envelope glycoproteins E1 and E2. These envelope proteins interact with a variety of specific and non-specific host membrane proteins (attachment factors and (co-)receptors) to initiate viral entry. Two of these receptors, CD81 and occluding, play a key role in determining host cell and species tropism [4-9]. The P7 protein is involved in ion channel activity and viral assembly $[10,11]$. The non-structural proteins include NS2, NS3, NS4A, NS4B, NS5A and NS5B. NS3/4A and NS5B function as viral protease and RNA dependent 
RNA polymerase (RdRp), respectively, and are evidently required for viral replication. The NS4B and NS5A proteins are involved in the formation of membranous web but NS5A also plays a major role in orchestrating viral replication and assembly [11].

\begin{tabular}{|c|c|c|c|c|c|c|c|c|c|c|c|}
\hline \multirow[b]{2}{*}{ 5' NTR } & \multicolumn{4}{|c|}{ Structural proteins } & \multicolumn{6}{|c|}{ Non-structural proteins } & \multirow[b]{2}{*}{ 3'NTR } \\
\hline & C & E1 & E2 & P7 & NS2 & NS3 & $4 A$ & NS4B & NS5A & NS5B & \\
\hline & & & & $\uparrow \uparrow$ & & & $\uparrow \uparrow$ & & & & \\
\hline & $\begin{array}{r}\text { DA } \\
\text { (h }\end{array}$ & $\begin{array}{l}\text { Ss ide } \\
\text { nized }\end{array}$ & $\begin{array}{l}\text { ed in } \\
\text { and }\end{array}$ & $\begin{array}{l}\text { nal mo } \\
\text { npanze }\end{array}$ & & $\begin{array}{r}\text { Protea } \\
\text { V36 } \\
\text { T54 } \\
\text { Q80I } \\
\text { R155 } \\
\text { A156S } \\
\text { D168V/C }\end{array}$ & & $\begin{array}{l}\text { NS4B } \\
\text { N99H }\end{array}$ & $\begin{array}{l}\text { NS5A } \\
\text { L31M/N } \\
\text { Y93H/C }\end{array}$ & $\begin{array}{c}\text { Polymerase } \\
\text { S282T } \\
\text { C316Y } \\
\text { Y448H } \\
\text { P495S/A } \\
\text { G554D } \\
\text { D559G }\end{array}$ & \\
\hline
\end{tabular}

Figure 1. Hepatitis $\mathrm{C}$ virus (HCV) genome structure and direct acting antiviral agents (DAAs)-resistance associated substitutions (RASs). After viral entry in the hepatocyte the genome of HCV is translated into a single polyprotein precursor which is cleaved by host peptidases (black arrows) to release the structural proteins (C, E1 and E2) followed by cleavage by viral proteases (blue arrows) to produce the non-structural proteins (NS2, NS3, NS4A, NS4B, NS5A and NS5B). The NS3/4A and NS5B function as viral protease and polymerase, respectively. Mutations associated with resistance to different protease, polymerase and NS5A inhibitors that were identified during studies in HCV animal models are listed. NTR: non-translated region.

The high replication rate (about $10^{12}$ newly produced virions per day) and the error-prone HCV polymerase $\left(10^{-3}-10^{-4}\right.$ substitutions per nucleotide per genome replication round) result in a cloud of closely related viral variants, known as quasispecies [12,13]. Within the quasispecies pool, variants will emerge that may be less sensitive to antiviral agents and which will become dominant within the population during drug pressure. A variety of non-structural proteins are the target of direct acting antiviral agents (DAAs). These include NS3-4A protease inhibitors, NS5A inhibitors and (non-)nucleos(t)ide NS5B polymerase inhibitors that possess distinct efficacy and genetic barrier to resistance. In addition, viral entry can be prevented by specifically blocking the envelope glycoproteins E1 and E2 or, in general, by targeting the viral particle with neutralizing antibodies or small molecules [14-21]. Besides viral proteins, also host cell factors that are involved in the HCV life cycle such as CD81, scavenger receptor class B type I (SR-BI), claudin-1, microRNA-122 (miR-122) and cyclophilin A can be antagonized as HCV treatment [22-29].

A 48-week combination therapy with pegylated interferon (PEG-IFN) and ribavirin (RBV) has long been the standard treatment protocol for chronic HCV infection. Besides low sustained virologic response (SVR), especially for some genotypes and people with certain genetic factors, the treatment was also accompanied by considerable side effects [30,31]. Telaprevir and boceprevir, in combination with PEG-IFN and RBV, were the first approved DAAs for HCV treatment [32]. Although this triple therapy improved response rates, especially for those patients infected with a genotype 1 virus and treatment-experienced patients, adverse effects including neutropenia, pruritus, anemia and thrombocytopenia have been reported at higher frequency than for the double therapy protocol [33]. In addition, because of their low genetic barrier to resistance, the triple therapy is usually accompanied by the emergence of resistant variants $[34,35]$. The preclinical evaluation of HCV drugs and their associated resistance had long been hampered by the lack of a robust small animal model for HCV infection. In this review, we give an overview of the currently available HCV in vivo models with an emphasis on their utility to study drug resistance. 


\section{Pre-Clinical in Vivo Models for HCV Treatment}

\subsection{Non-Rodent HCV Models}

The experimental infection of chimpanzees (Pan troglodytes) enabled the discovery and identification of $\mathrm{HCV}$ as the etiologic agent for non-A non-B viral hepatitis $[1,36]$. It has been valuable for deciphering host-virus interactions and preclinical analysis of antiviral strategies [37]. Programmed cell death 1 (PD-1) and miR-122 antagonizing therapies are only two such examples [27,38]. Despite the genomic homology between chimpanzees and humans, the natural course of infection differs since only few chimpanzees develop chronic HCV infection, no fibrosis and only one hepatocellular carcinoma (HCC) case has been observed [39]. In the context of antiviral efficacy studies, chimpanzees have been successfully used to track resistance associated with the use of entry [40], protease, NS5A [41] and polymerase [42,43] inhibitors, and their combinations [44]. Nonetheless, availability, cost, and, particularly, ethical constraints severely limit the use of these large primates for HCV research. Recently, the National Institutes of Health (NIH) of the United States Department of Health and Human Services decided to effectively end its support for invasive research on chimpanzees [45].

Tree shrews (Tupaia belangeri) are non-rodent squirrel-like mammals that were found to be permissive for HCV infection [46,47]. While HCV viremia could only be detected intermittently, some signs of histological progression to HCV-related liver disorders were observed [48]. Although tree shrews have been used to evaluate hepato-protective activity against HCV-induced liver damage, compatibility of the Tupaia host environment with HCV replication seems rather low.

\subsection{Rodent HCV Models}

Due to the narrow host tropism of HCV, the development of practical small animal models for $\mathrm{HCV}$, e.g., laboratory mice and rats, has been challenging [49]. Whilst rodents are naturally resistant to $\mathrm{HCV}$ infection different approaches have been undertaken to enable the study of the virus in mice. Of note, studies in HCV transgenic mice that express different, or a set of, viral proteins [50-55] have provided some insights in HCV pathogenesis but are less suited for screening HCV inhibitors. However, to productively match a human hepatotropic pathogen with a non-human liver, either the virus or the host should be adapted.

Although ongoing efforts are being made trying to adapt the virus to complete its life cycle in murine hepatocytes [56,57], no productive in vivo HCV infection has yet been reported in the absence of any human cofactor. One complementing strategy exists of transgenically supplementing mouse hepatocytes with essential human co-factors that would more efficiently support the HCV life cycle. Accordingly, adenoviral delivery of the human restriction factors CD81 and occludin (OCLN) allowed cell culture-derived HCV ( $\mathrm{HCV} c \mathrm{c}$ ) entry into the mouse hepatocytes and warranted evaluation of entry inhibitors and vaccine candidates $[5,16,21,58]$. Furthermore, mice transgenic for four human entry factors $(4 \mathrm{hEF})$ and deficient in several innate immune signaling pathways reproduced the HCV life cycle beyond viral entry, with infectious virus being recovered from the mouse serum [6]. Recently, infectivity of HCV infected patient serum was observed using a similar entry factor transgenic approach in mice with intact innate immune system, albeit with very low level of viremia [59]. Of note, a two-week telaprevir treatment successfully reduced viremia in these transgenic mice challenged with a JFH1-based inoculum.

The approach that led to the most extensively used HCV animal model, has been the xenotransplantation of a human-liver derived tissue in mice. Huh7 cells (i.e., human hepatoma cells that form the basis of in vitro HCV systems) that harbor a luciferase-based HCV subgenomic replicon have been transplanted into SCID/Beige mice, which enabled the study of $\mathrm{HCV}$ replication inhibitors [60]. Huh7 cells have also been transplanted in immunocompetent rats after in utero toleration. Although these Huh7-transplanted animals were shown to produce HCV viremia exceeding $10^{4}$ copies $/ \mathrm{mL}$, no infection data is available on tolerized rats transplanted with primary human hepatocytes [61]. One model that uses primary human liver tissue is the Trimera mouse, where small 
human liver fragments are transplanted under the kidney capsule or ear pinna. Ex vivo HCV challenge before extrahepatic implantation resulted in detectable viremia maintained for about one month [62]. Antiviral treatments tested in this model are an HCV internal ribosomal entry site inhibitor and anti-HCV human monoclonal antibodies $[62,63]$.

The first fully permissive murine model that supported long-term HCV infection was produced by intrasplenic injection of human hepatocytes into immune deficient mice with diseased liver, such as Alb-uPA/SCID and FRG mice (respectively, urokinase-type plasminogen activator transgenic severe combined immunodeficiency mice, and fumarylacetoacetate hydrolase-recombination activating gene 2-interleukin-2 receptor, common $\gamma$-chain knockout mice) [64-68]. Hepatotoxicity in the Alb-uPA/SCID mouse is induced by overexpression of the urokinase-type plasminogen activator protein, which is under the control of the mouse albumin promotor [69]. In the FRG model, deficiency of the fumarylacetoacetate hydrolase enzyme (FAH) leads to accumulation of tyrosine catabolites that are toxic to mouse hepatocytes. The tyrosine catabolism pathway can be blocked upstream of the toxic metabolites by oral administration of 2-(2-nitro-4-trifluoromethylbenzoyl)-1,3 cyclohexanedione (NTBC) [68]. This allows easy control and induction of the liver toxicity. Although these two recipient mouse lines were predominantly used for generating human-liver chimeric mice [70], susceptibility to HCV infection has also been shown in MUP-uPA and TK-NOG mice [71,72]. All these models are based on constitutive or inducible mouse hepatocyte death, and severely attenuated cellular rejection, providing a favorable niche for the transplanted human hepatocytes to engraft and repopulate the mouse liver. This process results in mice with a human chimeric liver that renders them highly susceptible for human hepatotropic pathogens, and hence enables the study of HCV biology and evaluation of different antiviral strategies [70].

$\mathrm{HCV}$ that is present in the blood of infected patients is associated with host lipoproteins and circulates in the form of lipoviral particles (LVPs). Besides their role in viral infectivity, lipoprotein incorporation plays a major role in viral escape from host neutralizing antibodies [73-75]. Using a model encompassing the entire viral life cycle would be of great importance for studying the biophysical properties of different HCV particles. Differences between HCV produced in cell culture and viral particles circulating in the blood of infected patients have been extensively described. Since cell cultures generally do not support infection of clinical HCV isolates, in vivo models represent a valuable tool for studying HCV isolated from clinical samples. Although chimpanzees have been used to determine the biophysical properties of HCV particles [76], the immune competence of such animals may influence to some extent the characteristics of HCV virions via the presence of HCV-specific antibodies. Interestingly, blood samples isolated from (uninfected) mice with humanized liver showed a human like lipoprotein profile [77]. Infectivity and lipoprotein incorporation in LVPs has been tested in $\mathrm{HCV} c \mathrm{c}$ and $\mathrm{mHCV} c \mathrm{HCV}$ (H passaged in humanized mice) using density gradient ultracentrifugation [78-80]. These studies showed a density profile of viral particles isolated from chimpanzees and humanized mice similar to that observed in humans, but different from that of particles produced in cell culture. This was further corroborated recently by Calattini et al. who presented a comprehensive characterization of HCV particles isolated from humanized mice and cell culture [81]. The infectious HCV particles retrieved from mouse plasma displayed lower densities and high enrichment with apolipoprotein $\mathrm{E}$, which has an impact on viral infectivity and receptor usage. Finally, mice humanized with both liver and immune cells are being developed that could provide new tools for studying immunopathogenesis, primary (human) adaptive immune response and vaccine strategies [82-87].

\section{Principles of HCV Resistance}

During the last few years, several DAAs including NS3/4A (protease), NS5A and NS5B (polymerase) inhibitors have been developed for HCV treatment [88-91]. The SVR achieved depends on several factors including the potency of the drug used and its genetic barrier to resistance, the regimen used, viral genotype/subtype and the presence/emergence of resistant variants. Since 
the viral polymerase lacks proofreading activity, closely related variants are continuously produced during the viral replication cycle. Most of resistance-associated substitutions (RASs) affect the viral fitness, especially those related to protease inhibitors (PIs), and hence could be found at low rates in treatment-naive patients [88-90,92]. Due to the selective pressure of DAAs, the wild type virus declines during therapy while resistant variants persist. Additional (compensatory) mutations are introduced and improve the viral fitness leading to viral breakthrough and treatment failure [89]. The possibility of viral relapse is related to different factors including the use of sub-optimal dose of the drug, a short duration therapy and the presence of resistant variants (possibly at low frequency below the limit of detection). Finally, the genetic barrier to resistance of the DAAs used plays a crucial role in success / failure of treatment. DAAs with a low barrier to resistance only need a few mutations (one or two substitutions) to confer resistance while multiple substitutions are required in case of DAAs with high barrier to resistance.

In the context of DAA-based therapy, several RASs including V36A/M, T54A/S, V55A, Q80K, R155K/T, A156T/S/V, D168A/E/T/V/N, V170A for PIs [32,89,90,93,94], M28T/V, Q30E/R/H, L31M/V, Y93H/C/N for NS5A inhibitors [90,95-98] and L159F, S282T, C316N, V321I/A, M426L, Y448H, Y452H R465G, V499A for polymerase inhibitors have been reported [99-101]. The resistance profile is genotype and subtype specific. For example, the PI-RASs V36M, T54S, R155K were reported in genotype 1a; V36A, T54S/A, A156S, V170A for genotype 1b; while the resistant variant D168Q is a natural polymorphism in genotype 3 [94,102]. Although resistant variants could be found at low frequency at baseline, they are dominant at treatment failure. A wide distribution of HCV-RASs in treatment-naive patients has been shown, including V36M, T54S, V55A, Q80K, R155K, V170A (NS3-RASs), L31M, Y93H as NS5A-RASs; and L159F, V321A/I, C316N, M426L, Y448H, Y452H, R465G, V499A, S556G as NS5B-RASs [91,99,101,103-107]. The impact of baseline RASs on treatment outcome depends on several factors including the type and frequency of RASs, the DAAs regimen used, the stage of liver disease, the prior DAAs treatment (treatment-experienced patients) and the virus genotype.

Treatment of HCV using a combination of two or more of DAAs has dramatically improved the SVR (>90\%). For example, the use of ledipasvir/sofosbuvir with or without RBV for genotype $1 \mathrm{~b}$ treatment resulted in an SVR12 > 95\%, although NS5A-RAS Y93H was detected at baseline [108]. Also, the use of ombitasvir/paritaprevir/ritonavir combination therapy for genotype 1b PEG-IFN/RBV-experienced patients resulted in $>88.9 \%$ SVR24 whereas a combination of the RASs NS3-D168V and NS5A-Y93H were found at the time of failure [109]. The use of dasabuvir/ombitasvir/paritaprevir/ritonavir with RBV for 12 weeks achieved SVR > 95\% for genotypes $1 \mathrm{a}$ and $1 \mathrm{~b}$ [110]. The most frequent variants found at the time of failure or relapse were D168V (NS3-RAS); M28T, Q30R, L31M, Y93H (NS5A-RASs); and S556G (NS5B-RAS) [110]. Recently, Pawlotsky provided a comprehensive overview on the different IFN-free DAAs regimens used for HCV treatment, concurrently proposing replacement of the term resistance associated variants (RAVs) by either "resistance associated substitution" (RAS) or "resistant variant" (RV) depending on whether reference is made to, respectively, the amino acid mutation that confers resistance or the resistant virus itself [89].

Interestingly, combination of daclatasvir with its analogue Syn-395 showed enhanced antiviral activity against NS5A resistant variants in vitro and in humanized mice [111]. This new finding paves the way for new regimens using DAAs from the same class that might improve the efficacy against resistant variants in treatment-experienced patients. Although the presence of RASs at baseline cannot predict treatment failure, screening at baseline for presence/frequency of those RASs leading to a high level of resistance is recommended (especially in DAAs-experienced and cirrhotic patients) in order to preclude the development of RV with multidrug resistance.

\section{HCV Therapy Studies with Resistance Profiling in Human-Liver Mice}

Besides chimpanzee, the human-liver chimeric mouse has been the only pre-clinical in vivo model used to monitor HCV drug resistance. As seen in the clinic, HCV treatment success is strongly dependent on the viral inoculum used to infect the animals. Besides genotype-specific treatment 
responses, multiple studies have confirmed expected decreased response rates after challenge with viral variants known to be resistant to the investigated drug. Indeed, pre-existing Q80K mutants in NS3, that confer partial resistance to PIs, were identified in both the inoculum and sera from mice that rebounded during BILN2061 (PI) therapy [112]. Virus from patient sera resistant to telaprevir (PI), mainly harboring the A156F mutation, was shown to be resistant to telaprevir treatment in mice as well [34]. Hiraga et al. went on to demonstrate that mice infected with an A156S mutant strain showed strong resistance to telaprevir treatment. Interestingly, the mutated virus replicated at lower rate than its wild type and showed high frequency of V36A during telaprevir therapy (11\% at week 2$)$ that decreased after treatment cessation (to $0.98 \%$ ) before increasing again upon treatment re-initiation with higher dose (to $5.4 \%$ and $41.8 \%$ at week 1 and 4 respectively). Mice challenged with the wild type strain, however, first experienced rapid decline in viremia before telaprevir-resistant NS3 V36A variants started to emerge, suggesting that resistant HCV can be induced by mutation of the wild type strain in vivo. Another study from the same group confirmed that administration of telaprevir for four weeks in humanized mice results in a $2 \times \log _{10}$-fold reduction in HCV viremia before viral rebound with emergence of the V36A mutation [34,113].

Further research performed by Chayama's group was based on clonal infection (genotype 1b) confirming poor response to telaprevir of the NS3 V36A mutant, while remaining responsive to a sequential telaprevir-NS5A inhibitor (BMS-788329) combination therapy [114]. Then, they wanted to show the response of an NS5A-resistant variant (with RAS L31V) in a similar treatment schedule consisting of a sequential therapy of only BMS-788329 first, before addition of telaprevir to the therapeutic cocktail. While the L31V mutant was expected to be sufficient to confer resistance to BMS-788329, it only responded poorly upon accumulating an additional Y93C mutation. Under supplementary telaprevir pressure, this double mutant was able to accumulate a third mutation, resulting in the emergence of the NS5A/telaprevir-resistant NS5A L31V-Y93C/NS3 V36A variant. As expected, this triple-mutant emerged again under the same treatment conditions upon initial challenge with the NS5A double mutant (L31V-Y93C). However, in this case also the NS3 T54A mutant emerged. Replacing telaprevir by an NS5B inhibitor (BMS-821095) rapidly selected a fifth NS5B P495S mutation showing on-therapy breakthrough. In a similar therapeutic setup, although the initial challenge was done with the triple mutant (NS5A L31V-Y93C/NS3 V36A), the NS5B P495S variant rebounded after cessation of NS5A-NS5B inhibitor double therapy. Altogether, this study nicely highlights the issue of multi-drug resistant variant selection upon inappropriate sequential use of viral inhibitors. Very recently, mice challenged with HCV harboring the RASs: D168V, L31V and Y93H (isolated from a patient that failed asunaprevir (PI)/daclatasvir (NS5A-I) therapy) not only were resistant to this very same combination, but also to ledipasvir (NS5A-I)/GS-558093 (a NS5B inhibitor similar to sofosbuvir), while responding to telaprevir (PI)/GS-558093 therapy [115]. Most recently, the monotherapy of GSK9574, a prodrug for the NS4B inhibitor GSK8853, in HCV genotype 1a infected mice resulted in 3x $\log _{10}$-fold decline in viremia with the emergence of the RASs N56I and N99H in NS4B [116].

Treatment of mice with the NS5B inhibitor MK-0608 resulted in an initial $2.6 \times \log _{10}$ decline in viremia before viral rebound and emergence of an NS5B S282T-containing resistant variant [113], similar to observations in chimpanzees [42,113]. Combination therapy of MK-0608 and telaprevir resulted in a decline of viremia to undetectable levels followed by viral rebound after cessation of therapy. However, no sequencing data is shown on these rebounding viral populations [113]. Of note, this combinatory regimen resulted in sustained virologic response upon addition of IFN-alpha or increased dosing of MK-0608. Together with a chimpanzee study [44], these were the first preclinical results suggesting that combination therapy using highly potent DAAs only, thus without IFN/RBV, is able to prevent resistance that could lead to viral rebound. Other pre-clinical evidence for the potential success of IFN/RBV free regimens using combination of different DAA classes is reported by Shi et al. [117]. While monotherapy of HCV genotype $1 \mathrm{~b}$ infected mice with either the PI BMS-605339, NS5A inhibitor BMS-788329 or NS5B inhibitor BMS-821095 failed eradicating the virus due to resistant variants emergence during treatment (RASs D168E, Y93H, and P495A/S respectively), the combination 
of the NS5A inhibitor with either the PI or NS5B inhibitor was sufficient [117]. Of note, the same therapy was not as successful in the context of genotype $2 a$ or $2 b$ infections, hence providing useful genotype-specific preclinical treatment outcome information.

Human-liver chimeric mice have also been challenged with core mutants. One study described the further selection of the R70Q core mutant upon PEG-IFN/RBV treatment in mice injected with a sample obtained from a patient on PEG-IFN/RBV treatment $[118,119]$. However, another study that investigated the impact of R70Q and L91M core substitutions on response to IFN treatment in mice did not observe decreased susceptibility $[118,119]$. In addition, the model has been used to test the effect of, and identify resistant variants selected during, alternative anti-HCV approaches. For example, synthetic hairpin-shaped RNAs that can degrade the virus' RNA genome effectively reduced the viral load before slowly rebounding after therapy cessation [120]. A follow-up study confirmed that this viral rebound was indeed due to emergence of a virus whose genome was mutated in the sequences targeted by the RNAs $[120,121]$.

Very recently, our group reported data indicating that inclusion of an entry inhibitor to the newest DAA combination therapies may further increase response rates by preventing therapeutic failure caused by on-therapy breakthrough of DAA-resistant variants [122]. We first confirmed that HCV infected human-liver mice receiving DAA-monotherapy rapidly experienced on-therapy viral breakthrough. Deep sequencing analysis identified the manifestation of drug-resistant mutants upon viral rebound. However, when an entry inhibitor was added to the antiviral regimen, not a single mouse experienced on-therapy viral breakthrough despite selection of resistant variants in some of these animals. We hypothesized that the intrahepatic spread of resistant variants selected during the DAA therapy was efficiently blocked by the entry inhibitor [122].

Although the failure of DAA treatment is potentially related to the development of resistant variants during therapy, clonal and deep sequencing analyses revealed the presence of certain RASs at baseline. This might increase the risk of therapy failure upon treatment with different protease [123-127], polymerase [99,125,127-130] or NS5A inhibitors [95,99,127,131]. While most protease inhibitor resistant variants have reduced fitness compared to the wild type virus and hence rapidly disappear after cessation of therapy, other variants especially with mutations in NS5A (e.g., L31M and Y93H) can persist for a long time. Recently, ultra-deep sequencing showed that failure of asunaprevir and daclatasvir combination therapy in chronic patients might be associated with the emergence of the RASs L31M, Y93H and D168A/V variants [132,133]. In a study involving mice infected with genotype $1 \mathrm{~b}$ quasispecies pool comprising PI-resistant virus, response to treatment with asunaprevir alone or in combination with daclatasvir correlated with the baseline frequency of these resistant variants [134]. In this study, resistant variants with RASs at NS3-D168 replaced the wild type virus upon administration of simeprevir. Inoculation of naive mice with these variants resulted in cross-resistance to asunaprevir, especially in mice in which the frequency of the RV was high. Similarly, the presence of D168 RASs at baseline resulted in a rebound of viremia after combination therapy of asunaprevir and daclatasvir [134]. Most recently, combination therapy of the PI vaniprevir and the NS5A inhibitor BMS-788329 eradicated HCV in genotype $1 \mathrm{~b}$ chronically infected mice compared to viral breakthrough seen in mice treated with vaniprevir alone, especially in those mice which had high viremia [135]. Deep sequencing showed the presence of the RASs D168V/G/A in mice with vaniprevir treatment failure [135]. The above-mentioned studies clearly present human liver chimeric mice as a valuable model for the detailed study of treatment-associated resistance. Such studies could help in identifying new highly potent inhibitors with a high barrier to resistance or for the prediction of the optimal DAA treatment combination that can be effectively used against a viral quasispecies containing single or multiple RVs (Figure 2). 


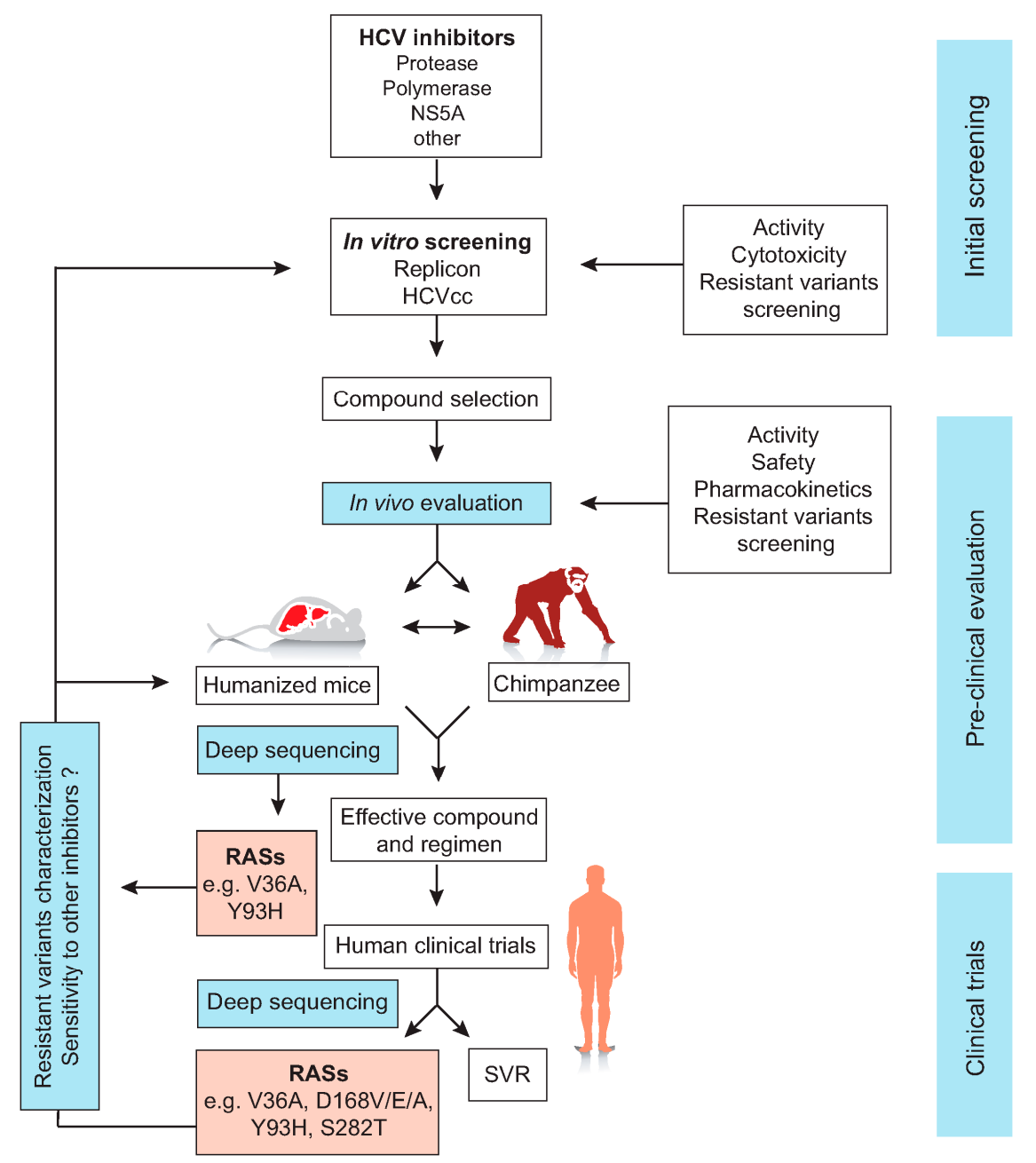

Figure 2. The sequence of HCV treatment and screening for resistance associated substitutions (RASs) and resistant variants. HCV protease, polymerase and NS5A inhibitors are screened first using HCV cell culture systems including HCV replicons and HCVcc models. Promising compounds with high potency and lowest cytotoxicity are then evaluated in vivo using the human liver chimeric mice and/or chimpanzee to test the pharmacokinetics, activity, safety and the emergence of resistant variants. Compounds with highest antiviral activity in vitro and in vivo could be then used in human clinical trials. If RASs are detected during clinical studies, the resistant variants could be further studied in vitro using replicons or HCVcc systems and in vivo using humanized mice or the chimpanzee. Such additional characterization studies would allow the evaluation of their sensitivity to other viral inhibitors. During therapy, the development of RASs could be identified using the clonal or deep sequencing (adapted from de Jong et al. 2011) [136].

\section{Conclusions}

With the advent of deep-sequencing technology, which can detect mutants at much lower frequency than before, mutational analysis is becoming more and more available. The greatly improved sensitivity over techniques such as clonal and population sequencing is also particularly valuable in extracting the maximum possible information from limited sample size inherent to the use of small animal model systems. HCV therapy studies performed in chimpanzees and human-liver chimeric mice prove the relevance of these models in the context of antiviral resistance and confirm drug class-specific resistance profiles observed in cell culture systems and clinical trials. Either the animals responded less well to therapy after being challenged with virus that already harbored known RASs (clinical isolates or genetically engineered), or these mutants could be readily detected upon sequencing 
of on-therapy breakthrough or post-therapy relapse viral populations. We therefore believe that these animal models nicely bridge the gap between in vitro HCV systems and clinical trials. Of note, we have recently shown that human-liver mice challenged with $\mathrm{HCV}$ variants that show increased resistance to SR-BI blockade in vitro, can still be fully protected from infection by an anti-SR-BI mAb [79]. This highlights discrepancies that still exist between cell culture and animal systems and advocates that interpretation and extrapolation of in vitro findings should be done with caution.

Today, the most relevant preclinical small animal model for HCV therapy is the human-liver chimeric mouse. The Chayama's group pioneered the use of such humanized mice for the analysis of resistant HCV mutants emerging during DAA therapy and for the validation of RASs identified in cell culture and clinical studies. They were among the first to provide pre-clinical evidence that DAA combinations of different classes, without IFN or RBV, were sufficient to reach sustained virologic response $[113,117]$. Their work also underscored that inappropriate sequential use of viral inhibitors efficiently selects for multi-drug resistant variants [114]. Recent work from our group in this model indicates that entry inhibitors can be used in combination with DAAs to prevent on-therapy breakthrough of DAA-resistant variants, thereby drastically improving end-of-treatment outcome [122]. Altogether, human-liver chimeric mice have been successfully used as a preclinical model to evaluate HCV therapeutics and monitor the development of resistant variants that are associated with their use (Figure 2). Considering the ethical constraints, limited availability and the high costs associated with chimpanzee studies, it is foreseeable that the human-liver chimeric mouse model will be the gold standard for preclinical in vivo evaluation of HCV treatment associated resistance.

Acknowledgments: A.A.M. is a recipient of a PhD fellowship provided by the Egyptian Government. K.V. is supported by a Fellowship of the Belgian American Educational Foundation. P.M. is supported by the Ghent University (Concerted Action Grant 01 G01712 and IRO project MODEL-HEPE), The Research Foundation-Flanders (FWO-Vlaanderen; project G0D2715N), the Agency for Innovation by Science and Technology (IWT SBO project HLIM-3D), the Belgian Science Policy Office (BELSPO, IUAP P7/47-HEPRO-2) and the European Union (FP7, HepaMab). Finally, we want to thank Julie Vercauteren and Lieven Verhoye for graphical assistance.

Author Contributions: A.A.M. and K.V. wrote the manuscript; and P.M. edited the manuscript.

Conflicts of Interest: The authors declare no conflict of interest.

\section{References}

1. Choo, Q.L.; Kuo, G.; Weiner, A.J.; Overby, L.R.; Bradley, D.W.; Houghton, M. Isolation of a cDNA clone derived from a blood-borne non-A, non-B viral-hepatitis genome. Science 1989, 244, 359-362. [CrossRef] [PubMed]

2. Hajarizadeh, B.; Grebely, J.; Dore, G.J. Epidemiology and natural history of HCV infection. Nat. Rev. Gastroenterol. Hepatol. 2013, 10, 553-562. [CrossRef] [PubMed]

3. Messina, J.P.; Humphreys, I.; Flaxman, A.; Brown, A.; Cooke, G.S.; Pybus, O.G.; Barnes, E. Global distribution and prevalence of hepatitis $C$ virus genotypes. Hepatology 2015, 61, 77-87. [CrossRef] [PubMed]

4. Vogt, A.; Scull, M.A.; Friling, T.; Horwitz, J.A.; Donovan, B.M.; Dorner, M.; Gerold, G.; Labitt, R.N.; Rice, C.M.; Ploss, A. Recapitulation of the hepatitis C virus life-cycle in engineered murine cell lines. Virology 2013, 444, 1-11. [CrossRef] [PubMed]

5. Dorner, M.; Horwitz, J.A.; Robbins, J.B.; Barry, W.T.; Feng, Q.; Mu, K.; Jones, C.T.; Schoggins, J.W.; Catanese, M.T.; Burton, D.R.; et al. A genetically humanized mouse model for hepatitis C virus infection. Nature 2011, 474, U208-U246. [CrossRef] [PubMed]

6. Dorner, M.; Horwitz, J.A.; Donovan, B.M.; Labitt, R.N.; Budell, W.C.; Friling, T.; Vogt, A.; Catanese, M.T.; Satoh, T.; Kawai, T.; et al. Completion of the entire hepatitis $C$ virus life cycle in genetically humanized mice. Nature 2013, 501, 237-241. [CrossRef] [PubMed]

7. Michta, M.L.; Hopcraft, S.E.; Narbus, C.M.; Kratovac, Z.; Israelow, B.; Sourisseau, M.; Evans, M.J. Species-specific regions of occludin required by hepatitis C virus for cell entry. J. Virol. 2010, 84, 11696-11708. [CrossRef] [PubMed] 
8. Ploss, A.; Evans, M.J.; Gaysinskaya, V.A.; Panis, M.; You, H.N.; de Jong, Y.P.; Rice, C.M. Human occludin is a hepatitis C virus entry factor required for infection of mouse cells. Nature 2009, 457, 882-886. [CrossRef] [PubMed]

9. Shirasago, Y.; Shimizu, Y.; Tanida, I.; Suzuki, T.; Suzuki, R.; Sugiyama, K.; Wakita, T.; Hanada, K.; Yagi, K.; Kondoh, M.; et al. Occludin-knockout human hepatic huh7.5.1-8-derived cells are completely resistant to hepatitis C virus infection. Biol. Pharm. Bull. 2016, 39, 839-848. [CrossRef] [PubMed]

10. Madan, V.; Bartenschlager, R. Structural and functional properties of the hepatitis $C$ virus $p 7$ viroporin. Viruses 2015, 7, 4461-4481. [CrossRef] [PubMed]

11. Bartenschlager, R.; Penin, F.; Lohmann, V.; Andre, P. Assembly of infectious hepatitis C virus particles. Trends Microbiol. 2011, 19, 95-103. [CrossRef] [PubMed]

12. Neumann, A.U.; Lam, N.P.; Dahari, H.; Gretch, D.R.; Wiley, T.E.; Layden, T.J.; Perelson, A.S. Hepatitis C viral dynamics in vivo and the antiviral efficacy of interferon-alpha therapy. Science 1998, 282, 103-107. [CrossRef] [PubMed]

13. Cuevas, J.M.; Gonzalez-Candelas, F.; Moya, A.; Sanjuan, R. Effect of ribavirin on the mutation rate and spectrum of hepatitis C virus in vivo. J. Virol. 2009, 83, 5760-5764. [CrossRef] [PubMed]

14. Meuleman, P.; Bukh, J.; Verhoye, L.; Farhoudi, A.; Vanwolleghem, T.; Wang, R.Y.; Desombere, I.; Alter, H.; Purcell, R.H.; Leroux-Roels, G. In vivo evaluation of the cross-genotype neutralizing activity of polyclonal antibodies against hepatitis C virus. Hepatology 2011, 53, 755-762. [CrossRef] [PubMed]

15. Law, M.; Maruyama, T.; Lewis, J.; Giang, E.; Tarr, A.W.; Stamataki, Z.; Gastaminza, P.; Chisari, F.V.; Jones, I.M.; Fox, R.I.; et al. Broadly neutralizing antibodies protect against hepatitis $\mathrm{C}$ virus quasispecies challenge. Nat. Med. 2008, 14, 25-27. [CrossRef] [PubMed]

16. Perin, P.M.; Haid, S.; Brown, R.J.P.; Doerrbecker, J.; Schulze, K.; Zeilinger, C.; von Schaewen, M.; Heller, B.; Vercauteren, K.; Luxenburger, E.; et al. Flunarizine prevents hepatitis C virus membrane fusion in a genotype-dependent manner by targeting the potential fusion peptide within E1. Hepatology 2016, 63, 49-62. [CrossRef] [PubMed]

17. Calland, N.; Albecka, A.; Belouzard, S.; Wychowski, C.; Duverlie, G.; Descamps, V.; Hober, D.; Dubuisson, J.; Rouille, Y.; Seron, K. (-)-epigallocatechin-3-gallate is a new inhibitor of hepatitis C virus entry. Hepatology 2012, 55, 720-729. [CrossRef] [PubMed]

18. Ciesek, S.; von Hahn, T.; Colpitts, C.C.; Schang, L.M.; Friesland, M.; Steinmann, J.; Manns, M.P.; Ott, M.; Wedemeyer, H.; Meuleman, P.; et al. The green tea polyphenol, epigallocatechin-3-gallate, inhibits hepatitis C virus entry. Hepatology 2011, 54, 1947-1955. [CrossRef] [PubMed]

19. Calland, N.; Sahuc, M.E.; Belouzard, S.; Pene, V.; Bonnafous, P.; Mesalam, A.A.; Deloison, G.; Descamps, V.; Sahpaz, S.; Wychowski, C.; et al. Polyphenols inhibit hepatitis $C$ virus entry by a new mechanism of action. J. Virol. 2015, 89, 10053-10063. [CrossRef] [PubMed]

20. Haid, S.; Novodomska, A.; Gentzsch, J.; Grethe, C.; Geuenich, S.; Bankwitz, D.; Chhatwal, P.; Jannack, B.; Hennebelle, T.; Bailleul, F.; et al. A plant-derived flavonoid inhibits entry of all HCV genotypes into human hepatocytes. Gastroenterology 2012, 143, U213-U772. [CrossRef] [PubMed]

21. Anggakusuma; Colpitts, C.C.; Schang, L.M.; Rachmawati, H.; Frentzen, A.; Pfaender, S.; Behrendt, P.; Brown, R.J.P.; Bankwitz, D.; Steinmann, J.; et al. Turmeric curcumin inhibits entry of all hepatitis $C$ virus genotypes into human liver cells. Gut 2014, 63, 1137-1149. [CrossRef] [PubMed]

22. Meuleman, P.; Hesselgesser, J.; Paulson, M.; Vanwolleghem, T.; Desollibere, I.; Reiser, I.; Leroux-Roels, G. Anti-CD81 antibodies can prevent a hepatitis C virus infection in vivo. Hepatology 2008, 48, 1761-1768. [CrossRef] [PubMed]

23. Meuleman, P.; Catanese, M.T.; Verhoye, L.; Desombere, I.; Farhoudi, A.; Jones, C.T.; Sheahan, T.; Grzyb, K.; Cortese, R.; Rice, C.M.; et al. A human monoclonal antibody targeting scavenger receptor class B type I precludes hepatitis $C$ virus infection and viral spread in vitro and in vivo. Hepatology 2012, 55, 364-372. [CrossRef] [PubMed]

24. Mailly, L.; Xiao, F.; Lupberger, J.; Wilson, G.K.; Aubert, P.; Duong, F.H.; Calabrese, D.; Leboeuf, C.; Fofana, I.; Thumann, C.; et al. Clearance of persistent hepatitis $C$ virus infection in humanized mice using a claudin-1-targeting monoclonal antibody. Nat. Biotechnol. 2015, 33, 549-554. [CrossRef] [PubMed] 
25. Ottosen, S.; Parsley, T.B.; Yang, L.; Zeh, K.; van Doorn, L.J.; van der Veer, E.; Raney, A.K.; Hodges, M.R.; Patick, A.K. In vitro antiviral activity and preclinical and clinical resistance profile of miravirsen, a novel anti-hepatitis C virus therapeutic targeting the human factor miR-122. Antimicrob. Agents Chemother. 2015, 59, 599-608. [CrossRef] [PubMed]

26. Van der Ree, M.H.; van der Meer, A.J.; de Bruijne, J.; Maan, R.; van Vliet, A.; Welzel, T.M.; Zeuzem, S.; Lawitz, E.J.; Rodriguez-Torres, M.; Kupcova, V.; et al. Long-term safety and efficacy of microRNA-targeted therapy in chronic hepatitis C patients. Antivir. Res. 2014, 111, 53-59. [CrossRef] [PubMed]

27. Lanford, R.E.; Hildebrandt-Eriksen, E.S.; Petri, A.; Persson, R.; Lindow, M.; Munk, M.E.; Kauppinen, S.; Orum, $\mathrm{H}$. Therapeutic silencing of microRNA-122 in primates with chronic hepatitis $\mathrm{C}$ virus infection. Science 2010, 327, 198-201. [CrossRef] [PubMed]

28. Daito, T.; Watashi, K.; Sluder, A.; Ohashi, H.; Nakajima, S.; Borroto-Esoda, K.; Fujita, T.; Wakita, T. Cyclophilin inhibitors reduce phosphorylation of RNA-dependent protein kinase to restore expression of IFN-stimulated genes in HCV-infected cells. Gastroenterology 2014, 147, 463-472. [CrossRef] [PubMed]

29. Nakagawa, M.; Sakamoto, N.; Tanabe, Y.; Koyama, T.; Itsui, Y.; Takeda, Y.; Chen, C.H.; Kakinuma, S.; Oooka, S.; Maekawa, S.; et al. Suppression of hepatitis C virus replication by cyclosporin A is mediated by blockade of cyclophilins. Gastroenterology 2005, 129, 1031-1041. [CrossRef] [PubMed]

30. Fried, M.W.; Shiffman, M.L.; Reddy, K.R.; Smith, C.; Marinos, G.; Goncales, F.L.; Haussinger, D.; Diago, M.; Carosi, G.; Dhumeaux, D.; et al. Peginterferon alfa-2a plus ribavirin for chronic hepatitis C virus infection. N. Engl. J. Med. 2002, 347, 975-982. [CrossRef] [PubMed]

31. Ascione, A.; de Luca, M.; Tartaglione, M.T.; Lampasi, F.; di Costanzo, G.G.; Lanza, A.G.; Picciotto, F.P.; Marino-Marsilia, G.; Fontanella, L.; Leandro, G. Peginterferon alfa-2a plus ribavirin is more effective than peginterferon alfa-2b plus ribavirin for treating chronic hepatitis C virus infection. Gastroenterology 2010, 138, 116-122. [CrossRef] [PubMed]

32. Zeuzem, S.; Andreone, P.; Pol, S.; Lawitz, E.; Diago, M.; Roberts, S.; Focaccia, R.; Younossi, Z.; Foster, G.R.; Horban, A.; et al. Telaprevir for retreatment of HCV infection. N. Engl. J. Med. 2011, 364, 2417-2428. [CrossRef] [PubMed]

33. Chou, R.; Hartung, D.; Rahman, B.; Wasson, N.; Cottrell, E.B.; Fu, R.W. Comparative effectiveness of antiviral treatment for hepatitis $C$ virus infection in adults: A systematic review. Ann. Intern. Med. 2013, 158, 114-123. [CrossRef] [PubMed]

34. Hiraga, N.; Imamura, M.; Abe, H.; Hayes, C.N.; Kono, T.; Onishi, M.; Tsuge, M.; Takahashi, S.; Ochi, H.; Iwao, E.; et al. Rapid emergence of telaprevir resistant hepatitis $C$ virus strain from wildtype clone in vivo. Hepatology 2011, 54, 781-788. [CrossRef] [PubMed]

35. Macartney, M.J.; Irish, D.; Bridge, S.H.; Garcia-Diaz, A.; Booth, C.L.; McCormick, A.L.; Labbett, W.; Smith, C.; Velazquez, C.; Tanwar, S.; et al. Telaprevir or boceprevir based therapy for chronic hepatitis C infection: Development of resistance-associated variants in treatment failure. Antivir. Res. 2014, 105, 112-117. [CrossRef] [PubMed]

36. Weiner, A.J.; Kuo, G.; Bradley, D.W.; Bonino, F.; Saracco, G.; Lee, C.; Rosenblatt, J.; Choo, Q.L.; Houghton, M. Detection of hepatitis C viral sequences in non-A, non-B hepatitis. Lancet 1990, 335, 1-3. [CrossRef]

37. Bukh, J. A critical role for the chimpanzee model in the study of hepatitis C. Hepatology 2004, 39, 1469-1475. [CrossRef] [PubMed]

38. Fuller, M.J.; Callendret, B.; Zhu, B.G.; Freeman, G.J.; Hasselschwert, D.L.; Satterfield, W.; Sharpe, A.H.; Dustin, L.B.; Rice, C.M.; Grakoui, A.; et al. Immunotherapy of chronic hepatitis C virus infection with antibodies against programmed cell death-1 (PD-1). Proc. Natl. Acad. Sci. USA 2013, 110, 15001-15006. [CrossRef] [PubMed]

39. Muchmore, E.; Popper, H.; Peterson, D.A.; Miller, M.F.; Lieberman, H.M. Non-A, non-B hepatitis-related hepatocellular carcinoma in a chimpanzee. J. Med. Primatol. 1988, 17, 235-246. [PubMed]

40. Morin, T.J.; Broering, T.J.; Leav, B.A.; Blair, B.M.; Rowley, K.J.; Boucher, E.N.; Wang, Y.; Cheslock, P.S.; Knauber, M.; Olsen, D.B. Human monoclonal antibody HCV1 effectively prevents and treats HCV infection in chimpanzees. PLoS Pathog. 2012, 8, e1002895. [CrossRef] [PubMed]

41. Coburn, C.A.; Meinke, P.T.; Chang, W.; Fandozzi, C.M.; Graham, D.J.; Hu, B.; Huang, Q.; Kargman, S.; Kozlowski, J.; Liu, R.; et al. Discovery of MK-8742: An HCV NS5A inhibitor with broad genotype activity. Chemmedchem 2013, 8, 1930-1940. [CrossRef] [PubMed] 
42. Carroll, S.S.; Ludmerer, S.; Handt, L.; Koeplinger, K.; Zhang, N.Y.R.; Graham, D.; Davies, M.E.; MacCoss, M.; Hazuda, D.; Olsen, D.B. Robust antiviral efficacy upon administration of a nucleoside analog to hepatitis C virus-infected chimpanzees. Antimicrob. Agents Chemother. 2009, 53, 926-934. [CrossRef] [PubMed]

43. Chen, C.M.; He, Y.; Lu, L.; Lim, H.B.; Tripathi, R.L.; Middleton, T.; Hernandez, L.E.; Beno, D.W.; Long, M.A.; Kati, W.M.; et al. Activity of a potent hepatitis $C$ virus polymerase inhibitor in the chimpanzee model. Antimicrob. Agents Chemother. 2007, 51, 4290-4296. [CrossRef] [PubMed]

44. Olsen, D.B.; Davies, M.E.; Handt, L.; Koeplinger, K.; Zhang, N.R.; Ludmerer, S.W.; Graham, D.; Liverton, N.; MacCoss, M.; Hazuda, D.; et al. Sustained viral response in a hepatitis C virus-infected chimpanzee via a combination of direct-acting antiviral agents. Antimicrob. Agents Chemother. 2011, 55, 937-939. [CrossRef] [PubMed]

45. Kaiser, J. Nih to End All Support for Chimpanzee Research. Available online: http:/ /www.sciencemag.org/ news/2015/11/nih-end-all-support-chimpanzee-research (accessed on 10 December 2015).

46. Xie, Z.C.; Riezu-Boj, J.I.; Lasarte, J.J.; Guillen, J.; Su, J.H.; Civeira, M.P.; Prieto, J. Transmission of hepatitis C virus infection to tree shrews. Virology 1998, 244, 513-520. [CrossRef] [PubMed]

47. Xu, X.; Chen, H.; Cao, X.; Ben, K. Efficient infection of tree shrew (Tupaia belangeri) with hepatitis $\mathrm{C}$ virus grown in cell culture or from patient plasma. J. Gen. Virol. 2007, 88, 2504-2512. [CrossRef] [PubMed]

48. Amako, Y.; Tsukiyama-Kohara, K.; Katsume, A.; Hirata, Y.; Sekiguchi, S.; Tobita, Y.; Hayashi, Y.; Hishima, T.; Funata, N.; Yonekawa, H.; et al. Pathogenesis of hepatitis C virus infection in Tupaia belangeri. J. Virol. 2010, 84, 303-311. [CrossRef] [PubMed]

49. Mailly, L.; Robinet, E.; Meuleman, P.; Baumert, T.F.; Zeisel, M.B. Hepatitis C virus infection and related liver disease: The quest for the best animal model. Front. Microbiol. 2013, 4, 213. [CrossRef] [PubMed]

50. Hara, Y.; Yanatori, I.; Ikeda, M.; Kiyokage, E.; Nishina, S.; Tomiyama, Y.; Toida, K.; Kishi, F.; Kato, N.; Imamura, M.; et al. Hepatitis $C$ virus core protein suppresses mitophagy by interacting with parkin in the context of mitochondrial depolarization. Am. J. Pathol. 2014, 184, 3026-3039. [CrossRef] [PubMed]

51. Pasquinelli, C.; Shoenberger, J.M.; Chung, J.; Chang, K.M.; Guidotti, L.G.; Selby, M.; Berger, K.; Lesniewski, R.; Houghton, M.; Chisari, F.V. Hepatitis C virus core and E2 protein expression in transgenic mice. Hepatology 1997, 25, 719-727. [CrossRef] [PubMed]

52. Frelin, L.; Brenndorfer, E.D.; Ahlen, G.; Weiland, M.; Hultgren, C.; Alheim, M.; Glaumann, H.; Rozell, B.; Milich, D.R.; Bode, J.G.; et al. The hepatitis C virus and immune evasion: Non-structural 3/4A transgenic mice are resistant to lethal tumour necrosis factor alpha mediated liver disease. Gut 2006, 55, 1475-1483. [CrossRef] [PubMed]

53. Wang, A.G.; Moon, H.B.; Kim, J.M.; Hwang, S.B.; Yu, D.Y.; Lee, D.S. Expression of hepatitis C virus nonstructural 4B in transgenic mice. Exp. Mol. Med. 2006, 38, 241-246. [CrossRef] [PubMed]

54. Majumder, M.; Steele, R.; Ghosh, A.K.; Zhou, X.Y.; Thornburg, L.; Ray, R.; Phillips, N.J.; Ray, R.B. Expression of hepatitis $C$ virus non-structural 5A protein in the liver of transgenic mice. FEBS Lett. 2003, 555, 528-532. [CrossRef]

55. Lerat, H.; Honda, M.; Beard, M.R.; Loesch, K.; Sun, J.; Yang, Y.; Okuda, M.; Gosert, R.; Xiao, S.Y.; Weinman, S.A.; et al. Steatosis and liver cancer in transgenic mice expressing the structural and nonstructural proteins of hepatitis C virus. Gastroenterology 2002, 122, 352-365. [CrossRef] [PubMed]

56. Bitzegeio, J.; Bankwitz, D.; Hueging, K.; Haid, S.; Brohm, C.; Zeisel, M.B.; Herrmann, E.; Iken, M.; Ott, M.; Baumert, T.F.; et al. Adaptation of hepatitis C virus to mouse CD81 permits infection of mouse cells in the absence of human entry factors. PLoS Pathog. 2010. [CrossRef] [PubMed]

57. Frentzen, A.; Anggakusuma; Gurlevik, E.; Hueging, K.; Knocke, S.; Ginkel, C.; Brown, R.J.P.; Heim, M.; Dill, M.T.; Kroger, A.; et al. Cell entry, efficient RNA replication, and production of infectious hepatitis C virus progeny in mouse liver-derived cells. Hepatology 2014, 59, 78-88. [CrossRef] [PubMed]

58. Giang, E.; Dorner, M.; Prentoe, J.C.; Dreux, M.; Evans, M.J.; Bukh, J.; Rice, C.M.; Ploss, A.; Burton, D.R.; Law, M. Human broadly neutralizing antibodies to the envelope glycoprotein complex of hepatitis $C$ virus. Proc. Natl. Acad. Sci. USA 2012, 109, 6205-6210. [CrossRef] [PubMed]

59. Chen, J.Z.; Zhao, Y.; Zhang, C.; Chen, H.R.; Feng, J.; Chi, X.M.; Pan, Y.; Du, J.; Guo, M.; Cao, H.; et al. Persistent hepatitis $C$ virus infections and hepatopathological manifestations in immune-competent humanized mice. Cell Res. 2014, 24, 1050-1066. [CrossRef] [PubMed] 
60. Zhu, Q.; Oei, Y.; Mendel, D.B.; Garrett, E.N.; Patawaran, M.B.; Hollenbach, P.W.; Aukerman, S.L.; Weiner, A.J. Novel robust hepatitis C virus mouse efficacy model. Antimicrob. Agents Chemother. 2006, 50, 3260-3268. [CrossRef] [PubMed]

61. Wu, G.Y.; Konishi, M.; Walton, C.M.; Olive, D.; Hayashi, K.; Wu, C.H. A novel immunocompetent rat model of HCV infection and hepatitis. Gastroenterology 2005, 128, 1416-1423. [CrossRef] [PubMed]

62. Ilan, E.; Arazi, J.; Nussbaum, O.; Zauberman, A.; Eren, R.; Lubin, I.; Neville, L.; Ben-Moshe, O.; Kischitzky, A.; Litchi, A.; et al. The hepatitis C virus (HCV)-trimera mouse: A model for evaluation of agents against HCV. J. Infect. Dis. 2002, 185, 153-161. [CrossRef] [PubMed]

63. Eren, R.; Landstein, D.; Terkieltaub, D.; Nussbaum, O.; Zauberman, A.; Ben-Porath, J.; Gopher, J.; Buchnick, R.; Kovjazin, R.; Rosenthal-Galili, Z. Preclinical evaluation of two neutralizing human monoclonal antibodies against hepatitis $\mathrm{C}$ virus (HCV): A potential treatment to prevent $\mathrm{HCV}$ reinfection in liver transplant patients. J. Virol. 2006, 80, 2654-2664. [CrossRef] [PubMed]

64. Mercer, D.F.; Schiller, D.E.; Elliott, J.F.; Douglas, D.N.; Hao, C.H.; Rinfret, A.; Addison, W.R.; Fischer, K.P.; Churchill, T.A.; Lakey, J.R.T.; et al. Hepatitis C virus replication in mice with chimeric human livers. Nat. Med. 2001, 7, 927-933. [CrossRef] [PubMed]

65. Meuleman, P.; Libbrecht, L.; de Vos, R.; de Hemptinne, B.; Gevaert, K.; Vandekerckhove, J.; Roskams, T.; Leroux-Roels, G. Morphological and biochemical characterization of a human liver in a uPA-SCID mouse chimera. Hepatology 2005, 41, 847-856. [CrossRef] [PubMed]

66. Bissig, K.D.; Le, T.T.; Woods, N.B.; Verma, I.M. Repopulation of adult and neonatal mice with human hepatocytes: A chimeric animal model. Proc. Natl. Acad. Sci. USA 2007, 104, 20507-20511. [CrossRef] [PubMed]

67. Bissig, K.D.; Wieland, S.F.; Tran, P.; Isogawa, M.; Le, T.T.; Chisari, F.V.; Verma, I.M. Human liver chimeric mice provide a model for hepatitis B and C virus infection and treatment. J. Clin Invest. 2010, 120, 924-930. [CrossRef] [PubMed]

68. Azuma, H.; Paulk, N.; Ranade, A.; Dorrell, C.; Al-Dhalimy, M.; Ellis, E.; Strom, S.; Kay, M.A.; Finegold, M.; Grompe, M. Robust expansion of human hepatocytes in Fah(-/-)/Rag2(-/-)/Il2rg(-/-) mice. Nat. Biotechnol. 2007, 25, 903-910. [CrossRef] [PubMed]

69. Sandgren, E.P.; Palmiter, R.D.; Heckel, J.L.; Daugherty, C.C.; Brinster, R.L.; Degen, J.L. Complete hepatic regeneration after somatic deletion of an albumin-plasminogen activator transgene. Cell 1991, 66, 245-256. [CrossRef]

70. Vercauteren, K.; de Jong, Y.P.; Meuleman, P. HCV animal models and liver disease. J. Hepatol. 2014, 61, S26-S33. [CrossRef] [PubMed]

71. Tesfaye, A.; Stift, J.; Maric, D.; Cui, Q.W.; Dienes, H.P.; Feinstone, S.M. Chimeric mouse model for the infection of hepatitis B and C viruses. PLoS ONE 2013, 8, e77298. [CrossRef] [PubMed]

72. Kosaka, K.; Hiraga, N.; Imamura, M.; Yoshimi, S.; Murakami, E.; Nakahara, T.; Honda, Y.; Ono, A.; Kawaoka, T.; Tsuge, M.; et al. A novel TK-NOG based humanized mouse model for the study of HBV and HCV infections. Biochem. Biophys. Res. Commun. 2013, 441, 230-235. [CrossRef] [PubMed]

73. Vercauteren, K.; Mesalam, A.A.; Leroux-Roels, G.; Meuleman, P. Impact of lipids and lipoproteins on hepatitis C virus infection and virus neutralization. WJG 2014, 20, 15975-15991. [CrossRef] [PubMed]

74. Fauvelle, C.; Felmlee, D.J.; Crouchet, E.; Lee, J.; Heydmann, L.; Lefevre, M.; Magri, A.; Hiet, M.S.; Fofana, I.; Habersetzer, F.; et al. Apolipoprotein E mediates evasion from hepatitis $\mathrm{C}$ virus neutralizing antibodies. Gastroenterology 2016, 150, 206-217. [CrossRef] [PubMed]

75. Dao Thi, V.L.; Granier, C.; Zeisel, M.B.; Guerin, M.; Mancip, J.; Granio, O.; Penin, F.; Lavillette, D.; Bartenschlager, R.; Baumert, T.F.; et al. Characterization of hepatitis $C$ virus particle subpopulations reveals multiple usage of the scavenger receptor BI for entry steps. J. Biol. Chem. 2012, 287, 31242-31257. [CrossRef] [PubMed]

76. Bradley, D.; Mccaustland, K.; Krawczynski, K.; Spelbring, J.; Humphrey, C.; Cook, E.H. Hepatitis C virus: buoyant density of the factor VIII-derived isolate in sucrose. J. Med. Virol. 1991, 34, 206-208. [CrossRef] [PubMed]

77. Steenbergen, R.H.G.; Joyce, M.A.; Lund, G.; Lewis, J.; Chen, R.; Barsby, N.; Zhu, L.F.; Tyrrell, D.L.J.; Kneteman, N.M. Lipoprotein profiles in SCID/uPA mice transplanted with human hepatocytes become human-like and correlate with HCV infection success. Am. J. Physiol. Gastrointest Liver Physiol. 2010, 299, G844-G854. [CrossRef] [PubMed] 
78. Prentoe, J.; Verhoye, L.; Velazquez Moctezuma, R.; Buysschaert, C.; Farhoudi, A.; Wang, R.; Alter, H.; Meuleman, P.; Bukh, J. HVR1-mediated antibody evasion of highly infectious in vivo adapted HCV in humanised mice. Gut 2015. [CrossRef] [PubMed]

79. Vercauteren, K.; Van den Eede, N.; Mesalam, A.A.; Belouzard, S.; Catanese, M.T.; Bankwitz, D.; Wong-Staal, F.; Cortese, R.; Dubuisson, J.; Rice, C.M.; et al. Successful anti-scavenger receptor class B type I (SR-BI) monoclonal antibody therapy in humanized mice after challenge with $\mathrm{HCV}$ variants with in vitro resistance to SR-BI-targeting agents. Hepatology 2014, 60, 1508-1518. [CrossRef] [PubMed]

80. Lindenbach, B.D.; Meuleman, P.; Ploss, A.; Vanwolleghem, T.; Syder, A.J.; McKeating, J.A.; Lanford, R.E.; Feinstone, S.M.; Major, M.E.; Leroux-Roels, G.; et al. Cell culture-grown hepatitis $C$ virus is infectious in vivo and can be recultured in vitro. Proc. Natl. Acad. Sci. USA 2006, 103, 3805-3809. [CrossRef] [PubMed]

81. Calattini, S.; Fusil, F.; Mancip, J.; Thi, V.L.D.; Granier, C.; Gadot, N.; Scoazec, J.Y.; Zeisel, M.B.; Baumert, T.F.; Lavillette, D.; et al. Functional and biochemical characterization of hepatitis C virus (HCV) particles produced in a humanized liver mouse model. J. Biol. Chem. 2015, 290, 23173-23187. [CrossRef] [PubMed]

82. Strick-Marchand, H.; Dusseaux, M.; Darche, S.; Huntington, N.D.; Legrand, N.; Masse-Ranson, G.; Corcuff, E.; Ahodantin, J.; Weijer, K.; Spits, H.; et al. A novel mouse model for stable engraftment of a human immune system and human hepatocytes. PLoS ONE 2015, 10, e0119820.

83. Washburn, M.L.; Bility, M.T.; Zhang, L.G.; Kovalev, G.I.; Buntzman, A.; Frelinger, J.A.; Barry, W.; Ploss, A.; Rice, C.M.; Su, L.S. A humanized mouse model to study hepatitis $\mathrm{C}$ virus infection, immune response, and liver disease. Gastroenterology 2011, 140, 1334-1344. [CrossRef] [PubMed]

84. Gutti, T.L.; Knibbe, J.S.; Makarov, E.; Zhang, J.J.; Yannam, G.R.; Gorantla, S.; Sun, Y.M.; Mercer, D.F.; Suemizu, H.; Wisecarver, J.L.; et al. Human hepatocytes and hematolymphoid dual reconstitution in treosulfan-conditioned uPA-NOG mice. Am. J. Pathol. 2014, 184, 101-109. [CrossRef] [PubMed]

85. Wilson, E.M.; Bial, J.; Tarlow, B.; Bial, G.; Jensen, B.; Greiner, D.L.; Brehm, M.A.; Grompe, M. Extensive double humanization of both liver and hematopoiesis in FRGN mice. Stem Cell Res. 2014, 13, 404-412. [CrossRef] [PubMed]

86. Bility, M.T.; Cheng, L.; Zhang, Z.; Luan, Y.; Li, F.; Chi, L.Q.; Zhang, L.G.; Tu, Z.K.; Gao, Y.H.; Fu, Y.X.; et al. Hepatitis B virus infection and immunopathogenesis in a humanized mouse model: Induction of human-specific liver fibrosis and M2-like macrophages. PLoS Pathog. 2014. [CrossRef] [PubMed]

87. Rongvaux, A.; Willinger, T.; Martinek, J.; Strowig, T.; Gearty, S.V.; Teichmann, L.L.; Saito, Y.; Marches, F.; Halene, S.; Palucka, A.K.; et al. Development and function of human innate immune cells in a humanized mouse model. Nat. Biotechnol. 2014, 32, U364-U230. [CrossRef] [PubMed]

88. Poveda, E.; Wyles, D.L.; Mena, A.; Pedreira, J.D.; Castro-Iglesias, A.; Cachay, E. Update on hepatitis C virus resistance to direct-acting antiviral agents. Antivir. Res. 2014, 108, 181-191. [CrossRef] [PubMed]

89. Pawlotsky, J.M. Hepatitis C virus resistance to direct-acting antiviral drugs in interferon-free regimens. Gastroenterology 2016. [CrossRef] [PubMed]

90. Sarrazin, C. The importance of resistance to direct antiviral drugs in HCV infection in clinical practice. J. Hepatol. 2016, 64, 486-504. [CrossRef] [PubMed]

91. Lontok, E.; Harrington, P.; Howe, A.; Kieffer, T.; Lennerstrand, J.; Lenz, O.; McPhee, F.; Mo, H.; Parkin, N.; Pilot-Matias, T.; et al. Hepatitis $\mathrm{C}$ virus drug resistance-associated substitutions: State of the art summary. Hepatology 2015, 62, 1623-1632. [CrossRef] [PubMed]

92. Shimakami, T.; Welsch, C.; Yamane, D.; McGivern, D.R.; Yi, M.; Zeuzem, S.; Lemon, S.M. Protease inhibitor-resistant hepatitis $C$ virus mutants with reduced fitness from impaired production of infectious virus. Gastroenterology 2011, 140, 667-675. [CrossRef] [PubMed]

93. Sarrazin, C.; Zeuzem, S. Resistance to direct antiviral agents in patients with hepatitis C virus infection. Gastroenterology 2010, 138, 447-462. [CrossRef] [PubMed]

94. Kieffer, T.L.; de Meyer, S.; Bartels, D.J.; Sullivan, J.C.; Zhang, E.Z.; Tigges, A.; Dierynck, I.; Spanks, J.; Dorrian, J.; Jiang, M.; et al. Hepatitis C viral evolution in genotype 1 treatment-naive and treatment-experienced patients receiving telaprevir-based therapy in clinical trials. PLoS ONE 2012, 7, e34372. [CrossRef] [PubMed]

95. Plaza, Z.; Soriano, V.; Vispo, E.; Gonzalez, M.D.; Barreiro, P.; Seclen, E.; Poveda, E. Prevalence of natural polymorphisms at the HCV NS5A gene associated with resistance to daclatasvir, an NS5A inhibitor. Antivir. Ther. 2012, 17, 921-926. [CrossRef] [PubMed] 
96. Fridell, R.A.; Wang, C.F.; Sun, J.H.; O’Boyle, D.R.; Nower, P.; Valera, L.; Qiu, D.; Roberts, S.; Huang, X.; Kienzle, B.; et al. Genotypic and phenotypic analysis of variants resistant to hepatitis $C$ virus nonstructural protein 5A replication complex inhibitor BMS-790052 in humans: In vitro and in vivo correlations. Hepatology 2011, 54, 1924-1935. [CrossRef] [PubMed]

97. McPhee, F.; Hernandez, D.; Yu, F.; Ueland, J.; Chayama, K.; Toyota, J.; Izumi, N.; Yokosuka, O.; Kawada, N.; Osaki, Y.; et al. A description of virologic escape in HCV genotype 1-infected patients treated with daclatasvir (BMS-790052) in combination with ribavirin and peginterferon alfa-2a or peginterferon alfa-2b. J. Hepatol. 2012, 56, S473-S473.

98. Nguyen, L.T.; Hall, N.; Sheerin, D.; Carr, M.; de Gascun, C.F.; Irish Hepatitis, C.O.R.N. Naturally occurring HCV NS5A/B inhibitor resistance-associated mutations to direct-acting antivirals. Antivir. Ther. 2016. [CrossRef] [PubMed]

99. Paolucci, S.; Fiorina, L.; Mariani, B.; Gulminetti, R.; Novati, S.; Barbarini, G.; Bruno, R.; Baldanti, F. Naturally occurring resistance mutations to inhibitors of HCV NS5A region and NS5B polymerase in DAA treatment-naive patients. Virol. J. 2013. [CrossRef] [PubMed]

100. Lam, A.M.; Espiritu, C.; Bansal, S.; Steuer, H.M.M.; Niu, C.R.; Zennou, V.; Keilman, M.; Zhu, Y.A.; Lan, S.Y.; Otto, M.J.; et al. Genotype and subtype profiling of PSI-7977 as a nucleotide inhibitor of hepatitis $C$ virus. Antimicrob. Agents Chemother. 2012, 56, 3359-3368. [CrossRef] [PubMed]

101. Donaldson, E.F.; Harrington, P.R.; O’Rear, J.J.; Naeger, L.K. Clinical evidence and bioinformatics characterization of potential hepatitis C virus resistance pathways for sofosbuvir. Hepatology 2015, 61, 56-65. [CrossRef] [PubMed]

102. Ogert, R.A.; Howe, J.A.; Vierling, J.M.; Kwo, P.Y.; Lawitz, E.J.; McCone, J.; Schiff, E.R.; Pound, D.; Davis, M.N.; Gordon, S.C.; et al. Resistance-associated amino acid variants associated with boceprevir plus pegylated interferon-alpha $2 \mathrm{~b}$ and ribavirin in patients with chronic hepatitis $\mathrm{C}$ in the SPRINT-1 trial. Antivir. Ther. 2013, 18, 387-397. [PubMed]

103. Shepherd, S.J.; Abdelrahman, T.; MacLean, A.R.; Thomson, E.C.; Aitken, C.; Gunson, R.N. Prevalence of HCV NS3 pre-treatment resistance associated amino acid variants within a Scottish cohort. J. Clin. Virol. 2015, 65, 50-53. [CrossRef] [PubMed]

104. Bartels, D.J.; Zhou, Y.; Zhang, E.Z.; Marcial, M.; Byrn, R.A.; Pfeiffer, T.; Tigges, A.M.; Adiwijaya, B.S.; Lin, C.; Kwong, A.D.; et al. Natural prevalence of hepatitis $C$ virus variants with decreased sensitivity to NS3.4A protease inhibitors in treatment-naive subjects. J. Infect. Dis. 2008, 198, 800-807. [CrossRef] [PubMed]

105. Kuntzen, T.; Timm, J.; Berical, A.; Lennon, N.; Berlin, A.M.; Young, S.K.; Lee, B.; Heckerman, D.; Carlson, J.; Reyor, L.L.; et al. Naturally occurring dominant resistance mutations to hepatitis $C$ virus protease and polymerase inhibitors in treatment-naive patients. Hepatology 2008, 48, 1769-1778. [CrossRef] [PubMed]

106. Lenz, O.; Verbinnen, T.; Fevery, B.; Tambuyzer, L.; Vijgen, L.; Peeters, M.; Buelens, A.; Ceulemans, H.; Beumont, M.; Picchio, G.; et al. Virology analyses of HCV isolates from genotype 1-infected patients treated with simeprevir plus peginterferon/ribavirin in phase IIb/III studies. J. Hepatol. 2015, 62, 1008-1014. [CrossRef] [PubMed]

107. Bagaglio, S.; Andolina, A.; Merli, M.; Uberti-Foppa, C.; Morsica, G. Frequency of natural resistance within NS5A replication complex domain in hepatitis C genotypes $1 \mathrm{a}, 1 \mathrm{~b}$ : Possible implication of subtype-specific resistance selection in multiple direct acting antivirals drugs combination treatment. Viruses 2016. [CrossRef] [PubMed]

108. Mizokami, M.; Yokosuka, O.; Takehara, T.; Sakamoto, N.; Korenaga, M.; Mochizuki, H.; Nakane, K.; Enomoto, H.; Ikeda, F.; Yanase, M.; et al. Ledipasvir and sofosbuvir fixed-dose combination with and without ribavirin for 12 weeks in treatment-naive and previously treated Japanese patients with genotype 1 hepatitis C: An open-label, randomised, phase 3 trial. Lancet Infect. Dis. 2015, 15, 645-653. [CrossRef]

109. Chayama, K.; Notsumata, K.; Kurosaki, M.; Sato, K.; Rodrigues, L.; Setze, C.; Badri, P.; Pilot-Matias, T.; Vilchez, R.A.; Kumada, H. Randomized trial of interferon- and ribavirin-free ombitasvir/paritaprevir/ritonavir in treatment-experienced hepatitis C virus-infected patients. Hepatology 2015, 61, 1523-1532. [CrossRef] [PubMed]

110. Feld, J.J.; Kowdley, K.V.; Coakley, E.; Sigal, S.; Nelson, D.R.; Crawford, D.; Weiland, O.; Aguilar, H.; Xiong, J.; Pilot-Matias, T.; et al. Treatment of HCV with ABT-450/r-ombitasvir and dasabuvir with ribavirin. N. Engl. J. Med. 2014, 370, 1594-1603. [CrossRef] [PubMed] 
111. Sun, J.H.; O’Boyle, D.R., 2nd; Fridell, R.A.; Langley, D.R.; Wang, C.; Roberts, S.B.; Nower, P.; Johnson, B.M.; Moulin, F.; Nophsker, M.J.; et al. Resensitizing daclatasvir-resistant hepatitis C variants by allosteric modulation of NS5A. Nature 2015, 527, 245-248. [CrossRef] [PubMed]

112. Kneteman, N.M.; Weiner, A.J.; O'Connell, J.; Collett, M.; Gao, T.; Aukerman, L.; Kovelsky, R.; Ni, Z.J.; Zhu, Q.; Hashash, A.; et al. Anti-HCV therapies in chimeric SCID-Alb/uPA mice parallel outcomes in human clinical application. Hepatology 2006, 43, 1346-1353. [CrossRef] [PubMed]

113. Ohara, E.; Hiraga, N.; Imamura, M.; Iwao, E.; Kamiya, N.; Yamada, I.; Kono, T.; Onishi, M.; Hirata, D.; Mitsui, F.; et al. Elimination of hepatitis C virus by short term NS3-4A and NS5B inhibitor combination therapy in human hepatocyte chimeric mice. J. Hepatol. 2011, 54, 872-878. [CrossRef] [PubMed]

114. Abe, H.; Hayes, C.N.; Hiraga, N.; Imamura, M.; Tsuge, M.; Miki, D.; Takahashi, S.; Ochi, H.; Chayama, K. A translational study of resistance emergence using sequential direct-acting antiviral agents for hepatitis $\mathrm{C}$ using ultra-deep sequencing. Am. J. Gastroenterol. 2013, 108, 1464-1472. [CrossRef] [PubMed]

115. Kai, Y.; Hikita, H.; Tatsumi, T.; Nakabori, T.; Saito, Y.; Morishita, N.; Tanaka, S.; Nawa, T.; Oze, T.; Sakamori, R.; et al. Emergence of hepatitis C virus NS5A L31V plus $\mathrm{Y} 93 \mathrm{H}$ variant upon treatment failure of daclatasvir and asunaprevir is relatively resistant to ledipasvir and NS5B polymerase nucleotide inhibitor GS-558093 in human hepatocyte chimeric mice. J. Gastroenterol. 2015, 50, 1145-1150. [CrossRef] [PubMed]

116. Pouliot, J.J.; Thomson, M.; Xie, M.; Horton, J.; Johnson, J.; Krull, D.; Mathis, A.; Morikawa, Y.; Parks, D.; Peterson, R.; et al. Preclinical characterization and in vivo efficacy of GSK8853, a small molecule inhibitor of the hepatitis C virus NS4B protein. Antimicrob. Agents Chemother. 2015, 59, 6539-6550. [CrossRef] [PubMed]

117. Shi, N.; Hiraga, N.; Imamura, M.; Hayes, C.N.; Zhang, Y.Z.; Kosaka, K.; Okazaki, A.; Murakami, E.; Tsuge, M.; Abe, H.; et al. Combination therapies with NS5A, NS3 and NS5B inhibitors on different genotypes of hepatitis $\mathrm{C}$ virus in human hepatocyte chimeric mice. Gut 2013, 62, 1055-1061. [CrossRef] [PubMed]

118. Hiraga, N.; Abe, H.; Imamura, M.; Tsuge, M.; Takahashi, S.; Hayes, C.N.; Ochi, H.; Tateno, C.; Yoshizato, K.; Nakamura, Y.; et al. Impact of viral amino acid substitutions and host interleukin-28b polymorphism on replication and susceptibility to interferon of hepatitis C virus. Hepatology 2011, 54, 764-771. [CrossRef] [PubMed]

119. Kurbanov, F.; Tanaka, Y.; Matsuura, K.; Sugauchi, F.; Elkady, A.; Khan, A.; Hasegawa, I.; Ohno, T.; Tokuda, H.; Mizokami, M. Positive selection of core 70Q variant genotype $1 \mathrm{~b}$ hepatitis $\mathrm{C}$ virus strains induced by pegylated interferon and ribavirin. J. Infect. Dis. 2010, 201, 1663-1671. [CrossRef] [PubMed]

120. Ma, H.; Dallas, A.; Ilves, H.; Shorenstein, J.; MacLachlan, I.; Klumpp, K.; Johnston, B.H. Formulated minimal-length synthetic small hairpin RNAs are potent inhibitors of hepatitis $C$ virus in mice with humanized livers. Gastroenterology 2014, 146, 63-66. [CrossRef] [PubMed]

121. Dallas, A.; Ilves, H.; Ma, H.; Chin, D.J.; MacLachlan, I.; Klumpp, K.; Johnston, B.H. Inhibition of hepatitis C virus in chimeric mice by short synthetic hairpin RNAs: Sequence analysis of surviving virus shows added selective pressure of combination therapy. J. Virol. 2014, 88, 4647-4656. [CrossRef] [PubMed]

122. Vercauteren, K.; Brown, R.J.; Mesalam, A.A.; Doerrbecker, J.; Bhuju, S.; Geffers, R.; van den Eede, N.; McClure, C.P.; Troise, F.; Verhoye, L.; et al. Targeting a host-cell entry factor barricades antiviral-resistant $\mathrm{HCV}$ variants from on-therapy breakthrough in human-liver mice. Gut 2015. [CrossRef]

123. Lisboa-Neto, G.; Noble, C.F.; Pinho, J.R.R.; Malta, F.M.; Gomes-Gouvea, M.S.; Alvarado-Mora, M.V.; da Silva, M.H.; Leite, A.G.B.; Piccoli, L.Z.; Rodrigues, F.K.; et al. Resistance mutations are rare among protease inhibitor treatment-naive hepatitis $C$ genotype-1 patients with or without HIV coinfection. Antivir. Ther. 2015, 20, 281-287. [CrossRef] [PubMed]

124. Silva, T.; Cortes Martins, H.; Coutinho, R.; Leitao, E.; Silva, R.; Padua, E. Molecular characterization of hepatitis $\mathrm{C}$ virus for determination of subtypes and detection of resistance mutations to protease inhibitors in a group of intravenous drug users co-infected with HIV. J. Med. Virol. 2015, 87, 1549-1557. [CrossRef] [PubMed]

125. Aissa Larousse, J.; Trimoulet, P.; Recordon-Pinson, P.; Papuchon, J.; Azzouz, M.M.; Ben Mami, N.; Cheikh, I.; Triki, H.; Fleury, H. Natural prevalence of hepatitis C virus (HCV) variants resistant to protease and polymerase inhibitors in patients infected with HCV genotype 1 in Tunisia. J. Med. Virol. 2014, 86, 1350-1359. [CrossRef] [PubMed]

126. Franco, S.; Bellido, R.; Aparicio, E.; Canete, N.; Garcia-Retortillo, M.; Sola, R.; Tural, C.; Clotet, B.; Paredes, R.; Martinez, M.A. Natural prevalence of $\mathrm{HCV}$ minority variants that are highly resistant to NS3/4A protease inhibitors. J. Viral Hepat. 2011, 18, E578-E582. [CrossRef] [PubMed] 
127. Applegate, T.L.; Gaudieri, S.; Plauzolles, A.; Chopra, A.; Grebely, J.; Lucas, M.; Hellard, M.; Luciani, F.; Dore, G.J.; Matthews, G.V. Naturally occurring dominant drug resistance mutations occur infrequently in the setting of recently acquired hepatitis C. Antivir. Ther. 2015, 20, 199-208. [CrossRef] [PubMed]

128. Di Maio, V.C.; Cento, V.; Mirabelli, C.; Artese, A.; Costa, G.; Alcaro, S.; Perno, C.F.; Ceccherini-Silberstein, F. Hepatitis C virus genetic variability and the presence of NS5B resistance- associated mutations as natural polymorphisms in selected genotypes could affect the response to NS5B inhibitors. Antimicrob. Agents Chemother. 2014, 58, 2781-2797. [CrossRef] [PubMed]

129. Alves, R.; Queiroz, A.T.L.; Pessoa, M.G.; da Silva, E.F.; Mazo, D.F.C.; Carrilho, F.J.; Carvalho, R.J.; de Carvalho, I.M.V.G. The presence of resistance mutations to protease and polymerase inhibitors in hepatitis C virus sequences from the Los Alamos databank. J. Viral Hepat. 2013, 20, 414-421. [CrossRef] [PubMed]

130. Dryer, P.D.; Limketkai, B.N.; Martin, C.M.; Ma, G.; Sherman, K.E.; Taylor, L.E.; Mayer, K.H.; Jamieson, D.J.; Blackard, J.T. Screening for hepatitis $\mathrm{C}$ virus non-nucleotide resistance mutations in treatment-naive women. J. Antimicrob. Chemother. 2009, 64, 945-948. [CrossRef] [PubMed]

131. Hirotsu, Y.; Kanda, T.; Matsumura, H.; Moriyama, M.; Yokosuka, O.; Omata, M. HCV NS5A resistance-associated variants in a group of real-world Japanese patients chronically infected with HCV genotype 1b. Hepatol. Int. 2015, 9, 424-430. [CrossRef] [PubMed]

132. Yoshimi, S.; Imamura, M.; Murakami, E.; Hiraga, N.; Tsuge, M.; Kawakami, Y.; Aikata, H.; Abe, H.; Hayes, C.N.; Sasaki, T.; et al. Long term persistence of NS5A inhibitor-resistant hepatitis C virus in patients who failed daclatasvir and asunaprevir therapy. J. Med. Virol. 2015, 87, 1913-1920. [CrossRef] [PubMed]

133. Kosaka, K.; Imamura, M.; Hayes, C.N.; Abe, H.; Hiraga, N.; Yoshimi, S.; Murakami, E.; Kawaoka, T.; Tsuge, M.; Aikata, H.; et al. Emergence of resistant variants detected by ultra-deep sequencing after asunaprevir and daclatasvir combination therapy in patients infected with hepatitis C virus genotype 1. J. Viral Hepat. 2015, 22, 158-165. [CrossRef] [PubMed]

134. Kan, H.; Hiraga, N.; Imamura, M.; Hayes, C.N.; Uchida, T.; Miyaki, E.; Tsuge, M.; Abe, H.; Aikata, H.; Miki, D.; et al. Combination therapies with daclatasvir and asunaprevir on NS3-D168 mutated HCV in human hepatocyte chimeric mice. Antivir. Ther. 2015. [CrossRef] [PubMed]

135. Uchida, T.; Hiraga, N.; Imamura, M.; Yoshimi, S.; Kan, H.; Miyaki, E.; Tsuge, M.; Abe, H.; Hayes, C.N.; Aikata, H.; et al. Elimination of HCV via a non-ISG-mediated mechanism by vaniprevir and BMS-788329 combination therapy in human hepatocyte chimeric mice. Virus Res. 2015, 213, 62-68. [CrossRef] [PubMed]

136. De Jong, Y.P.; Rice, C.M.; Ploss, A. Evaluation of combination therapy against hepatitis C virus infection in human liver chimeric mice. J. Hepatol. 2011, 54, 848-850. [CrossRef] [PubMed] 